\title{
Hepatoprotective Effects of Milk Thistle (Silybum marianum) Seed Cakes during the Chicken Broiler Fattening
}

\author{
P. SUCHÝ, Jr. ${ }^{1}$, E. STRAKOVÁ², V. KUMMER ${ }^{3}$, I. HERZIG ${ }^{3}$, V. PÍSAŘÍKOVÁ ${ }^{3}$, R. BLECHOVÁ ${ }^{1}$, \\ J. MAS̆KOVÁ ${ }^{3}$ \\ ${ }^{1}$ Department of Human Pharmacology and Toxicology \\ ${ }^{2}$ Department of Nutrition, Zootechnics and Zoohygiene \\ University of Veterinary and Pharmaceutical Sciences, Brno, Czech Republic \\ ${ }^{3}$ Veterinary Research Institute, Brno, Czech Republic
}

Received February 16, 2007

Accepted November 15, 2007

\begin{abstract}
Suchý Jr. P., E. Straková, V. Kummer, I. Herzig, V. Písaříková, R. Blechová, J. Mašková: Hepatoprotective Effects of Milk Thistle (Silybum marianum) Seed Cakes during the Chicken Broiler Fattening. Acta Vet. Brno 2008, 77: 31-38.

The objective of this work was to verify the hepatoprotective effects of Silybum marianum seed cakes in feed mixtures used for the fattening of chicken broilers to heavier weights. Part of the experiment was to verify the preventive effect of such modified feed mixtures with the use of chlortetracycline medication. The experiment was carried out on 180 ROSS 308 broiler chickens. The chickens were fed complete feed mixtures containing $0.0 \%(\mathrm{~K}), 0.2 \%(\mathrm{P} 1$ and $1.0 \%$ (P2) of Silybum marianum seed cakes. The cakes used contained $2.95 \%$ of silymarin. On the $44^{\text {th }}$ day of fattening half of the chickens from every group were supplied with chlortetracycline medicated water at a dose of $2 \mathrm{~g} \cdot \mathrm{kg}^{1}$ live weight. The selected biochemical indices were observed: cholesterol (Chol), glutamyl transferase (GMT), aspartate aminotransferase (AST), and alanine aminotransferase (ALT). On the $52^{\text {nd }}$ day of the test, six chickens from each group were euthanized and their liver was taken for histological examination. Adding Silybum marianum seed cakes resulted in a non-significant decrease in the chickens' live weight and in the feed conversion in both experimental groups compared to the control group. The cholesterol levels were highly significantly lower $(p<0.01)$ on the $43^{\text {rd }}$ day in group $\mathrm{P} 2$, and significantly lower $(p<0.05)$ on the $52^{\text {nd }}$ day in group P1 when compared to the control group (K). Also the ALT and AST activity was lower $(p<0.01)$ in both experimental groups on the $22^{\text {nd }}$ day of the experiment. On the $52^{\text {nd }}$ day the lower activity $(p<0.01)$ was found only for AST in both experimental groups. In the chlortetracycline medicated group P2, cholesterol level $(p<0.05)$ as well as ALT activity and AST activity decreased $(p<0.01)$, compared to the medicated control group. Results of biochemical analyses were also confirmed by histological examination of the liver. Administration of silymarin reduced $(p<0.01)$ the content of lipids and increased the content of glycogen in the liver of both experimental groups.
\end{abstract}

Feed supplement, silymarin, performance, chlortetracycline, liver, histology

Silybum marianum seeds have been used for almost 2000 years as a natural medicament for the liver and biliary duct. Silymarin presents a pharmacologically effective substance containing four main constituents: silybin (50 - 60\%), isosilybin (5\%), silychristin $(20 \%)$ and silydianin (10\%) (Ding et al. 2001). Available literature sources state that silymarin acts in four different ways: as an antioxidant, absorber and regulator of the intracellular glutathione; as a stabiliser and regulator of cell membrane permeability that prevents the entering of hepatotoxic substances into hepatocytes; as the ribosomal RNA synthesis promoter simulating regeneration of the liver; and as an inhibitor of the transformation of liver stellate cells into myofibroblasts - the process responsible for deposition of collagen fibres in liver. Furthermore, absorption of free radicals is considered to be one of the key mechanisms securing liver protection (Fraschini et al. 2002).

Although silymarin has commonly been used in human clinical practice for quite a

Address for correspondence:

MVDr. Pavel Suchý, Ph.D.

Department of Human Pharmacology and Toxicology

Faculty of Pharmacy

University of Veterinary and Pharmaceutical Sciences Brno

Palackeho 1-3, 61242 Brno, Czech Republic

Phone: +420541562891

Fax: +420541240605

E-mail: suchypa@vfu.cz

http://www.vfu.cz/acta-vet/actavet.htm 
long time, some mechanisms of its hepatoprotective effect have not been discovered yet. Crocenzi and Roma (2006) point out its potent anticholestatic activity in their review of clinical studies regarding the hepatoprotective effect of silymarin. Škottová and Krečman (1998) suggest the possibility of a direct impact of silymarin on the cholesterol metabolism by means of its biosynthesis inhibition.

In humans, the Silybum marianum seed formulas are often used in cases of acute mushroom poisoning by Amanita phalloides, and in patients with an alcoholic liver disease (Saller et al. 2001; Wellington and Jarvis 2001). Many scientists point out the anticancer potential of silymarin as it is able to suppress the proliferation of tumour cells (prostate, breast, ovary, colon, lung and bladder) (Agarwal et al. 2006; Singh and Agarwal 2004). The protective effect of silymarin on pancreatic damage induced by alloxan is also important (Soto et al. 2003), as well as hyperglycaemia reduction and reversion of the pancreatic damage in alloxan treated rats (Soto et al. 2004).

Silymarin has had a good safety record and only in rare cases have there been reports of gastrointestinal disturbances (nausea and epigastric discomfort), arthralgia, headache, and allergic skin rashes (Saller et al. 2001; Wellington and Jarvis 2001).

The effects of silymarin or various products made from the seed of the plant Silybum marianum containing silymarin have also been tested on farm animals. The hepatoprotective activities were assessed on the basis of selected biochemical blood indicators in chicken broilers that had been exposed to the effects of aflatoxins (Sujatha et al. 2003; Tedesco et al. 2004). Similar hepatoprotective activities of silymarin were observed in a case of aflatoxin B1 application to sewer rats (Rastogi et al. 2000). The effectiveness of silymarin was also confirmed in dogs and cats when administering large doses of oxytetracycline which has a hepatotoxic effect (Vijayakumar et al. 2004).

Except for the observed biochemical blood indicators in experimental animals, it is also possible to carry out the histopathological examination of the liver to prove the hepatoprotective effect of silymarin (Crocenzi and Roma 2006; Gawel et al. 2003; Jacobs et al. 2002). Furthermore, Salmi and Sarna (1982) and Buzzelli et al. (1993) state the normalisation of histological findings accompanied by a decrease in AST, ALT and GMT activities in cases of lighter forms of chronic hepatitis.

Many scientists have focused on the effect of products made from Silybum marianum seeds containing silymarin regarding utility indicators in chicken broilers (Mekala et al. 2006; Gawel et al. 2003; Wojcik et al. 2002). However, the results of these experiments are not uniform or are even contradictory regarding the observed utility indicators.

The aim of our work was to verify the hepatoprotective effects of the Silybum marianum seed cakes in feed mixtures that are used for fattening chicken broilers to heavier weights. A part of the experiment was to verify the preventive effect of thus modified feed mixtures in the case of chlortetracycline therapy or preventive medication by chlortetracycline.

\section{Materials and Methods}

The experiment was carried out in the accredited experimental stables of the Department of Nutrition, Zootechnics and Zoohygiene of the University of Veterinary and Pharmaceutical Sciences, Brno. A total of 180 one-day-old ROSS 308 chicken broilers were used in the experiment. They were divided into three groups of 60 specimens each (K, P1 and P2). Chickens in group K were fed complete commercial feed mixtures BR1 and BR2; group P1 was fed the same mixtures with $0.2 \%$ of groats containing Silybum marianum seed cakes; and group P2 was fed a mixture with $1 \%$ of groats containing Silybum marianum seed cakes. The used cakes contained $2.95 \%$ of silymarin. The content of the feed mixtures is given in Table 1.

All groups were raised at one facility with separated aviaries; the conditions and technological requirements regarding the ROSS 308 chickens were also observed, including the health condition, live weight and feed consumption.

On the $44^{\text {th }}$ day of fattening the chickens were separated into six groups of 30 specimens each, using the method of analogous couples (according to sex and live weight): $\mathrm{K}(+)$ and $\mathrm{K}(-) ; \mathrm{P} 1(+)$ and P1(-); P2(+) and P2(-). Chickens in the groups marked $\mathrm{K}(+), \mathrm{P} 1(+)$ and $\mathrm{P} 2(+)$ were supplied with chlortetracycline medicated water 
Table 1. Composition of used feed mixtures $\left(\mathrm{g} \cdot \mathrm{kg}^{-1}\right)$

\begin{tabular}{|c|c|c|c|c|c|c|}
\hline & \multicolumn{3}{|c|}{ BR1 $\left(1^{\text {st }}-22^{\text {nd }}\right.$ day of fattening $)$} & \multicolumn{3}{|c|}{ BR2 $\left(23^{\text {rd }}-52^{\text {nd }}\right.$ day of fattening $)$} \\
\hline & $\mathrm{K}$ & P1 & P2 & $\mathrm{K}$ & P1 & P2 \\
\hline \multirow{2}{*}{$\begin{array}{l}\text { Dry matter } \\
\text { Crude protein }\end{array}$} & 895.0 & 896.3 & 8998.6 & 892.8 & 891.6 & 892.5 \\
\hline & 234.4 & 225.9 & 227.2 & 215.7 & 207.3 & 216.1 \\
\hline \multirow{3}{*}{$\begin{array}{l}\text { Fat } \\
\text { Fibre } \\
\text { Ash }\end{array}$} & $\begin{array}{l}50.9 \\
\end{array}$ & 53.8 & 47.1 & 43.5 & 43.4 & 43.3 \\
\hline & 16.7 & 21.2 & 20.4 & 20.9 & 20.3 & 20.2 \\
\hline & 64.2 & 63.1 & 63.1 & 60.6 & 61.1 & 60.5 \\
\hline \multirow{2}{*}{$\begin{array}{l}\mathrm{Ca} \\
\mathrm{P}\end{array}$} & 14.8 & 14.4 & 14.4 & 13.5 & 13.6 & 13.6 \\
\hline & 8.1 & 8.7 & 8.2 & 7.4 & 8.0 & 8.0 \\
\hline \multirow{2}{*}{$\begin{array}{l}\mathrm{Mg} \\
\mathrm{NaCl}\end{array}$} & 1.5 & 1.6 & 1.5 & 1.9 & 1.9 & 1.9 \\
\hline & 4.1 & 4.1 & 4.1 & 2.5 & 2.5 & 2.9 \\
\hline
\end{tabular}

(UNI-CTC 100, Univit Uničov, Czech Republic) in such a way that the daily dose of CTC was $2 \mathrm{~g} / 10 \mathrm{~kg}$ of live weight/day).

On the $22^{\text {nd }}, 43^{\text {rd }}$ and $52^{\text {nd }}$ day of the experiment, twelve chickens randomly selected from each group had their blood samples taken from vena basilica. Selected biochemical indices: cholesterol (Chol), glutamyl transferase (GMT), aspartate aminotransferase (AST) and alanine aminotransferase (ALT) were measured by the Cobas EMira biochemical analyser using commercial test kits (Biovendor - Laboratorní medicína, a.s., CZ).

On the $52^{\text {nd }}$ day of the experiment six chickens from each group were euthanized and their liver was taken for histological examination. Liver samples were fixed in the Baker's liquid fixative for $24 \mathrm{~h}$ at the temperature of $4{ }^{\circ} \mathrm{C}$. Then the cryostat-cut sections were prepared $(7 \mu \mathrm{m})$. Staining with oil red (Sigma) was used for the histochemical identification of lipids in the liver tissue, and the PAS reaction (Vacek 1990) for glycogen identification. The content of lipids was assessed semi-quantitatively according to the extent of the liver tissue infiltration, and according to the character of the fat drops using the following range: 0 - without signs of lipid accumulation; 10 - small fat drops form, affecting up to $25 \%$ of the tissue area; 20 - small fat drops form, affecting up to $50 \%$ of the area with first signs of hepatocyte dystrophy; 30 - mixed form, affecting up to $75 \%$ of the area with distinct signs of hepatocyte dystrophy; 40 - big fat drops of steatosis form, affecting almost the whole tissue area, distinct hepatocyte dystrophy. The mean was calculated on the basis of the values acquired for the individual control and experimental groups. Computer image analysis based on the LUCIA G programme (Laboratory Imaging, Prague, Czech Republic) was used to determine the area of the liver tissue infiltrated by lipids. The following grades were used for the semi-quantitative assessment of the glycogen content: 10 - low, 20 - medium and 30 - high content of glycogen in hepatocytes.

The results were analysed using the statistical package STAT Plus; values were compared by unpaired $t$-test (Matoušková et al. 1992).

\section{Results and Discussion}

The summary of the observed performance variables is listed in Table 2. The adding of lower (P1) and higher (P2) portion of Silybum marianum seed cakes into the feed mixtures resulted in a decrease in the weight gain and a non-significant lower live weight of chickens during fattening. Furthermore, a lower feed conversion in both experimental groups was noted, namely by $7.65 \%(\mathrm{P} 1)$ and $6.12 \%(\mathrm{P} 2)$ compared to the control group (K). Wojcik et al. (2002) found similar results when they supplied fattened chicken broilers with a silymarin supplement. They discovered lower slaughter weight as well as poorer feed conversion compared to the control group. Gawel et al. (2003), on the other hand, observed an increase in the slaughter weight in chicken broilers and turkeys when supplied with silymarin. Chlortetracycline medicated water (CTC) did not have a significant impact on the live weight of chickens in any group. The results of the observed utility indicators during the CTC administering are listed in Table 3.

The results of the blood plasma biochemical analyses are listed in Tables 4 and 5. The highly significantly lower concentration of cholesterol in blood plasma was determined in group P2 on the $43^{\text {rd }}$ day of the experiment compared to the control group. This outcome was confirmed on the $52^{\text {nd }}$ day when the significantly lower blood plasma cholesterol in group P1(-) and a non-significantly lower level in group P2(-) was discovered. Administration 
Table 2. Performance indicators

\begin{tabular}{|c|c|c|c|c|c|}
\hline & & $\begin{array}{c}\mathrm{n} \\
(\mathrm{pcs})\end{array}$ & $\begin{array}{c}\text { Live weight } \\
(\mathrm{kg} \pm \mathrm{SD})\end{array}$ & $\begin{array}{c}\text { Weight gain } \\
\left(\mathrm{g} \cdot \text { day }^{-1}\right)\end{array}$ & $\begin{array}{c}\text { Feed conversion } \\
\left(\mathrm{kg}^{-1} \mathrm{~kg}^{-1}\right)\end{array}$ \\
\hline \multirow{3}{*}{$1^{\text {st }}-22^{\text {nd }}$ day } & $\mathrm{K}$ & 60 & $0.656 \pm 0.079$ & 30.0 & 2.10 \\
\cline { 2 - 6 } & $\mathrm{P} 1$ & 60 & $0.662 \pm 0.086$ & 30.1 & 2.02 \\
\cline { 2 - 6 } & $\mathrm{P} 2$ & 60 & $0.650 \pm 0.105$ & 29.5 & 2.00 \\
\hline \multirow{3}{*}{$1^{\text {st }}-43^{\text {rd }}$ day } & $\mathrm{K}$ & 60 & $2.260 \pm 0.274$ & 52.6 & 1.84 \\
\cline { 2 - 6 } & $\mathrm{P} 1$ & 60 & $2.140 \pm 0.324$ & 49.8 & 1.82 \\
\cline { 2 - 6 } & $\mathrm{P} 2$ & 60 & $2.120 \pm 0.276$ & 49.3 & 1.90 \\
\hline \multirow{3}{*}{$1^{\text {st }}-52^{\text {nd }}$ day } & $\mathrm{K}$ & 60 & $2.890 \pm 0.371$ & 55.6 & 1.96 \\
\cline { 2 - 6 } & $\mathrm{P} 1$ & 60 & $2.650 \pm 0.345$ & 51.0 & 2.11 \\
\cline { 2 - 6 } & $\mathrm{P} 2$ & 60 & $2.650 \pm 0.326$ & 51.0 & 2.08 \\
\hline
\end{tabular}

Table 3. Performance indicators during the CTC application

\begin{tabular}{|c|c|c|c|c|c|c|}
\hline & & CTC & $\begin{array}{c}\mathrm{n} \\
(\mathrm{pcs})\end{array}$ & $\begin{array}{c}\text { Live weight } \\
(\mathrm{kg} \pm \mathrm{SD})\end{array}$ & $\begin{array}{c}\text { Weight gain } \\
\left(\mathrm{g} \cdot \mathrm{day}{ }^{-1}\right)\end{array}$ & $\begin{array}{c}\text { Feed conversion } \\
\left(\mathrm{kg}^{-1} \cdot \mathrm{kg}^{-1}\right)\end{array}$ \\
\hline \multirow{4}{*}{$44^{\text {th }}-52^{\text {nd }}$ day } & $\mathrm{K}$ & + & 30 & $2.900 \pm 0.368$ & 71.1 & 2.48 \\
\cline { 2 - 7 } & & - & 30 & $2.880 \pm 0.373$ & 70.0 & 2.25 \\
\cline { 2 - 7 } & P1 & + & 30 & $2.640 \pm 0.333$ & 58.9 & 2.80 \\
\cline { 2 - 7 } & & - & 30 & $2.660 \pm 0.357$ & 53.3 & 2.86 \\
\cline { 2 - 7 } & P2 & + & 30 & $2.720 \pm 0.357$ & 64.4 & 2.79 \\
\cline { 2 - 7 } & & - & 30 & $2.570 \pm 0.337$ & 53.3 & 2.81 \\
\hline
\end{tabular}

of CTC resulted in an increase in the cholesterol level in all groups; the increase was highly significant in group $\mathrm{P} 1(+)$. These results support the possibility of inhibition of the endogenic cholesterol synthesis in the liver by silymarin (Škottová and Krečman 1998).

The ALT activity in the blood plasma of both experimental groups on the $22^{\text {nd }}$ day of the fattening was significantly lower compared to the control group. However, this difference was not confirmed on the $43^{\text {rd }}$ day of fattening. The ALT activity was significantly increased at the last sampling (the $52^{\text {nd }}$ day of fattening). The difference between individual groups was not significant even though the ALT activity was significantly lower in group P2(+) that was given CTC, compared to the control group $\mathrm{K}(+)$. Tedesco et al. (2004) found a similar result when they tried to reduce the aflatoxin B-1 toxicity by administering silymarin to broiler chickens. The ALT activity in the blood plasma of aflatoxin-medicated chickens supplied with silymarin did not differ from the non-medicated control group in their experiment. Patients with chronic liver disorders experienced a decrease in ALT activity (Jacobs et al. 2002). However, Gordon et al. (2006) did not prove the significant decrease of ALT activity in patients suffering from chronic hepatitis when they were given formulas with Silybum marianum seeds.

The AST activity in blood plasma of the experimental groups during all examinations was lower compared to the control groups. On the $22^{\text {nd }}$ day of fattening the difference was highly significant. A decrease was found in the experimental groups compared to the control group during sampling on the $52^{\text {nd }}$ day. The AST activity remained high in the CTC medicated groups, except for group $\mathrm{P} 2(+)$, where the AST activity in blood plasma was lower compared to the control group $\mathrm{K}(+)$.

The GMT activity on the $43^{\text {rd }}$ day of fattening was significantly lower in group P2 compared to the control group and group P1. On the contrary, on the $52^{\text {nd }}$ day of fattening the differences between the individual groups were not significant either in the nonmedicated groups or in the groups with the liver damaged by the hepatotoxic effect of CTC. Nevertheless, an increase of transaminase activity in blood plasma including GMT in the case of toxic damage of liver is cited in the work of Rastogi et al. (2000). 
Table 4. Biochemical indicators of blood plasma on the $22^{\text {nd }}$ and $43^{\text {rd }}$ day of fattening (mean \pm SD)

\begin{tabular}{|c|c|c|c|c|}
\hline & & $\mathrm{n}(\mathrm{pcs})$ & $22^{\text {nd }}$ day & $43^{\text {rd }}$ day \\
\hline \multirow{3}{*}{$\begin{array}{l}\text { Cholesterol } \\
\left(\mathrm{mmol} \cdot 1^{-1}\right)\end{array}$} & $\mathrm{K}$ & 12 & $3.3 \pm 0.29$ & $3.8 \pm 0.25$ \\
\hline & $\mathrm{P} 1$ & 12 & $3.1 \pm 0.27$ & $3.6 \pm 0.44$ \\
\hline & $\mathrm{P} 2$ & 12 & $3.3 \pm 0.34$ & $3.3 \pm 0.44 * *$ \\
\hline \multirow{3}{*}{$\begin{array}{l}\text { GMT } \\
\left(\mu \mathrm{kat} \cdot 1^{-1}\right)\end{array}$} & $\mathrm{K}$ & 12 & $0.51 \pm 0.08$ & $0.68 \pm 0.13$ \\
\hline & $\mathrm{P} 1$ & 12 & $0.54 \pm 0.10$ & $0.71 \pm 0.14$ \\
\hline & $\mathrm{P} 2$ & 12 & $0.52 \pm 0.09$ & $0.58 \pm 0.10^{*}$ \\
\hline \multirow{3}{*}{$\begin{array}{l}\text { AST } \\
\left(\mu \mathrm{kat} \cdot 1^{-1}\right)\end{array}$} & $\mathrm{K}$ & 12 & $0.87 \pm 0.06$ & $0.90 \pm 0.05$ \\
\hline & $\mathrm{P} 1$ & 12 & $0.81 \pm 0.03 * *$ & $0.88 \pm 0.04$ \\
\hline & $\mathrm{P} 2$ & 12 & $0.81 \pm 0.04 * *$ & $0.89 \pm 0.05$ \\
\hline \multirow{3}{*}{$\begin{array}{l}\text { ALT } \\
\left(\mu \mathrm{kat} \cdot 1^{-1}\right)\end{array}$} & $\mathrm{K}$ & 12 & $0.14 \pm 0.02$ & $0.15 \pm 0.03$ \\
\hline & $\mathrm{P} 1$ & 12 & $0.08 \pm 0.02 * *$ & $0.15 \pm 0.03$ \\
\hline & $\mathrm{P} 2$ & 12 & $0.11 \pm 0.02 * *$ & $0.15 \pm 0.03$ \\
\hline
\end{tabular}

** Compared to the control; significant at $p<0.01$

* Compared to the control; significant at $p<0.05$

Table 5. Biochemical indicators of blood plasma on the $52^{\text {nd }}$ day of fattening (mean \pm SD)

\begin{tabular}{|c|c|c|c|c|}
\hline & & CTC & $\mathrm{n}(\mathrm{pcs})$ & $52^{\text {nd }}$ day \\
\hline \multirow{6}{*}{$\begin{array}{l}\text { Cholesterol } \\
\left(\mathrm{mmol} \cdot \mathrm{l}^{-1}\right)\end{array}$} & \multirow{2}{*}{$\mathrm{K}$} & - & 6 & $3.7 \pm 0.31$ \\
\hline & & + & 6 & $4.1 \pm 0.50$ \\
\hline & \multirow{2}{*}{$\mathrm{P} 1$} & - & 6 & $3.0 \pm 0.50 *$ \\
\hline & & + & 6 & $3.9 \pm 0.48++$ \\
\hline & \multirow{2}{*}{$\mathrm{P} 2$} & - & 6 & $3.3 \pm 0.39$ \\
\hline & & + & 6 & $3.4 \pm 0.34 *$ \\
\hline \multirow{6}{*}{$\begin{array}{l}\text { GMT } \\
\left(\mu \mathrm{kat} \cdot \mathrm{l}^{-1}\right)\end{array}$} & \multirow{2}{*}{$\mathrm{K}$} & - & 6 & $0.66 \pm 0.08$ \\
\hline & & + & 6 & $0.70 \pm 0.06$ \\
\hline & \multirow{2}{*}{$\mathrm{P} 1$} & - & 6 & $0.67 \pm 0.10$ \\
\hline & & + & 6 & $0.73 \pm 0.06$ \\
\hline & \multirow{2}{*}{$\mathrm{P} 2$} & - & 6 & $0.57 \pm 0.16$ \\
\hline & & + & 6 & $0.63 \pm 0.18$ \\
\hline \multirow{6}{*}{$\begin{array}{l}\text { AST } \\
\left(\mu \mathrm{kat} \cdot \mathrm{l}^{-1}\right)\end{array}$} & \multirow{2}{*}{$\mathrm{K}$} & - & 6 & $0.95 \pm 0.08$ \\
\hline & & + & 6 & $1.00 \pm 0.04$ \\
\hline & \multirow{2}{*}{$\mathrm{P} 1$} & - & 6 & $0.66 \pm 0.03 * *$ \\
\hline & & + & 6 & $0.93 \pm 0.12++$ \\
\hline & \multirow{2}{*}{$\mathrm{P} 2$} & - & 6 & $0.64 \pm 0.04 * *$ \\
\hline & & + & 6 & $0.68 \pm 0.04 * *$ \\
\hline \multirow{6}{*}{$\begin{array}{l}\text { ALT } \\
\left(\mu \mathrm{kat} \cdot \mathrm{l}^{-1}\right)\end{array}$} & \multirow{2}{*}{$\mathrm{K}$} & - & 6 & $0.76 \pm 0.06$ \\
\hline & & + & 6 & $0.78 \pm 0.04$ \\
\hline & \multirow{2}{*}{$\mathrm{P} 1$} & - & 6 & $0.73 \pm 0.02$ \\
\hline & & + & 6 & $0.74 \pm 0.02$ \\
\hline & \multirow[b]{2}{*}{$\mathrm{P} 2$} & - & 6 & $0.70 \pm 0.03$ \\
\hline & & + & 6 & $0.72 \pm 0.03^{*}$ \\
\hline
\end{tabular}

** Compared to the control; significant at $p<0.01$

* Compared to the control; significant at $p<0.05$

++ Compared to the CTC; significant at $p<0.01$

+ Compared to the CTC; significant at $p<0.05$

Results of the biochemical tests show damage to the chicken broiler's liver during their fattening to heavier weights, and confirm the hepatoprotective effect of silymarin contained in the cakes from the seeds of Silybum marianum. Many of the above-mentioned observations also confirmed the hepatoprotective effect of silymarin when substances with 
hepatotoxic effects were administered; in our study, it was chlortetracycline at a therapeutic dose reported by Vijayakumar et al. (2004), who found similar results during the testing of the hepatoprotective effect of silymarin on hepatotoxic oxytetracycline.

Table 6. Histological examination of lipids and glycogen in livers of the control and experimental groups of chicken

\begin{tabular}{|l|c|c|c|c|c|c|}
\hline \multicolumn{2}{|l|}{ Group } & $\mathrm{n}$ & $\begin{array}{c}\text { Number of } \\
\text { fields }\end{array}$ & $\begin{array}{c}\text { Lipidous tissue rate } \\
(\% \pm \mathrm{SEM})\end{array}$ & $\begin{array}{c}\text { Lipids } \\
(\text { degree 0-40) }\end{array}$ & $\begin{array}{c}\text { Glycogen } \\
(\text { degree } 0-30)\end{array}$ \\
\hline \multirow{2}{*}{$\mathrm{K}$} & $\mathrm{CTC}-$ & 6 & 30 & $46.9 \pm 3.6$ & 21.7 & 8.3 \\
\cline { 2 - 7 } & $\mathrm{CTC}+$ & 6 & 30 & $72.4 \pm 4.2++$ & 35.0 & 13.3 \\
\hline \multirow{2}{*}{ P1 } & CTC - & 6 & 30 & $11.4 \pm 1.8^{* *}$ & 6.7 & 28.3 \\
\cline { 2 - 7 } & CTC+ & 6 & 30 & $73.9 \pm 2.6++$ & 35.0 & 12.5 \\
\hline \multirow{2}{*}{ P2 } & CTC - & 6 & 30 & $26.5 \pm 4.8^{* *}$ & 14.2 & 25.0 \\
\cline { 2 - 7 } & CTC + & 5 & 25 & $46.6 \pm 7.5+* *$ & 21.0 & 26.0 \\
\hline
\end{tabular}

** Compared to the control; significant at $p<0.01$

* Compared to the control; significant at $p<0.05$

++ Compared to the CTC; significant at $p<0.01$

+ Compared to the CTC; significant at $p<0.05$

The above mentioned results were also confirmed by histological examination of the liver. Evaluation of the lipids and glycogen occurrence in the liver tissue of the observed chicken groups on the $52^{\text {nd }}$ day of fattening is summarised in Table 6 . It was proved that the CTC medication administered to chickens resulted in serious liver steatosis. The highest, massive degree of steatosis was determined in the groups $\mathrm{K}(+)$ and $\mathrm{P} 1(+)$. It is necessary to point out the fact that a relatively high degree of steatosis was also determined to be present in group $\mathrm{K}(-)$, i.e. the control group of intact chickens. The protective effect of silymarin against the hepatotoxic effect of CTC only appeared after administering higher doses to group $\mathrm{P} 2(+)$, where the steatosis degree was almost the same as in group $\mathrm{K}(-)$. Administration of silymarin significantly reduced the content of lipids in the liver of both experimental groups of chickens that were not administered CTC; namely under the values determined in the control group of intact chickens.

The highest glycogen content was found in both groups of chickens that were supplied with silymarin at higher doses, and in the cases of lower doses only in the group of the CTC nonmedicated chickens. Both control groups, the intact group and the CTC medicated chickens, had low glycogen content in hepatocytes. Gawel et al. (2003) proved the hepatoprotective effect of silymarin during fattening by histological examination of chicken broilers as well.

Results of the histological examination of the liver specimens are presented in Figs. 1 - 4 (Plates I and II).

Substantial liver steatosis was found in chicken broilers fattened for up to 52 days even when there was no further intervention (CTC application). The hepatoprotective effect of Silybum marianum seed cakes added to the chickens' feed mixtures resulted in lower cholesterol levels and lower activity of the observed enzymes in both experimental groups. These results were also confirmed by histological examination of the liver tissue.

In case of chlortetracycline therapy, the hepatoprotective effect of the Silybum marianum seed cakes was significant only in group P2 that was fed a complete feed mixture with higher portion of the cakes.

\section{Hepatoprotektivní účinky výlisků semen ostropestřce mariánského (Silybum marianum) při výkrmu kuřecích brojlerů}

Cílem práce bylo ověřit hepatoprotektivní účinky výlisků semen Silybum marianum v krmných směsích pro výkrm kurrecích brojlerů do vyšší hmotnosti. Součástí pokusu bylo 
ověření preventivního účinku takto modifikovaných krmných směsí při medikaci chlortetracyklinem. Pokus byl uskutečněn na 180 kusech brojlerových kuřat ROSS 308 . Kuřata byla krmena kompletními krmnými směsmi s obsahem 0,0\% (K), 0,2\% (P1) a 1,0\% (P2) výlisků semen Silybum marianum. Použité výlisky obsahovaly 2,95\% silymarinu. V 44. den výkrmu byl polovině kuřat každé ze skupiny do napájecí vody přidán chlortetracyklin $\mathrm{v}$ dávce $2 \mathrm{~g} \cdot \mathrm{kg}^{-1}$ ž.hm. Byly sledovány vybrané biochemické ukazatele: cholesterol (Chol), gamma-glutamyl transferasa (GMT), aspartát aminotransferasa (AST) a alanin aminotransferasa (ALT). V 52. den pokusu bylo z každé skupiny utraceno šest kusů kuřat a proveden odběr jater a jejich histologické vyšetření. Zařazení výlisků semen Silybum marianum vedlo k statisticky nevýznamnému snížení živé hmotnosti kuřat a konverze krmiva u obou pokusných skupin oproti kontrole. Hladina cholesterolu byla oproti kontrole statisticky vysoce významně nižší $(p<0,01) 43$. den u skupiny P2 a významně nižší $(p<0,05) 52$. den u skupiny P1. Nižší $(p<0,01)$ byla i aktivita ALT a AST u obou pokusných skupin 22. den pokusu, 52. den pokusu byla nižší $(p<0,01)$ aktivita prokázána pouze u AST v obou pokusných skupinách. U skupiny P2 medikované chlortetracyklinem došlo ke snížení $(p<0,05)$ hladiny cholesterolu, aktivity ALT a snížení $(p<0,01)$ aktivity AST oproti medikované kontrole. Výsledky biochemických analýz byly potvrzeny i histologickým vyšetřením. Podávání silymarinu snížilo $(p<0,01)$ obsah lipidů a zvýšilo obsah glykogenu v játrech obou pokusných skupin.

\section{Acknowledgement}

This study was supported by the Ministry of Agriculture of the Czech Republic (NAZV No. EP6619 and MZe No. 0002716201) and Ministry of Education, Youth and Sports of the Czech Project No. 6215712402.

\section{References}

AGARWAL R, AGARWAL C, ICHIKAWA H, SINGH RP, AGGARWAL BB 2006: Anticancer potential of silymarin: From bench to bed side. Anticancer Res 26: 4457-4498

BUZZELLI G, MOSCARELLA S, GIUSTI A, DUCHINI A, MARENA C, LAMPERTICO M 1993: A pilot-study on the liver protective effect of silybin-phosphatidylcholine complex (ldb1016) in chronic active hepatitis. Int J Clin Pharmacol Ther Toxicol 31: 456-460

CROCENZI FA, ROMA MG 2006: Silymarin as a new hepatoprotective agent in experimental cholestasis: New possibilities for an ancient medication. Curr Med Chem 13: 1055-1074

DING TM, TIAN SJ, ZHANG ZX, GU DZ, CHEN YF, SHI YH, SUN ZP 2001: Determination of active component in silymarin by RP-LC and LC/MS. J Pharm Biomed Anal 26: 155-161

FRASCHINI F, DEMARTINI G, ESPOSTI D 2002: Pharmacology of silymarin. Clin Drug Invest 22: 51-65

GAWEL A, KOTONSKI B, MADEJ JA, MAZURKIEWICZ M 2003: Effect of silimarin on chicken and turkey broilers' rearing and the production indices of reproduction hen flocks. Med Weter 59: 517-520

GORDON A, HOBBS DA, BOWDEN DS, BAILEY MJ, MITCHELL J, FRANCIS AJP, ROBERTS SK 2006: Effects of Silybum marianum on serum hepatitis C virus RNA, alanine aminotransferase levels and well-being in patients with chronic hepatitis C. J Gastroenterol Hepatol 21: 275-280

JACOBS BP, DENNEHY C, RAMIREZ G, SAPP J, LAWRENCE VA 2002: Milk thistle for the treatment of liver disease: A systematic review and meta-analysis. Am J Med 113: 506-515

MATOUŠKOVÁ O, CHALUPA J, CÍGLER M, HRUŠKA K.1992: Statistický program STAT Plus verze 1.01. Brno;Výzkumný ústav veterinárního lékařství, 1992: software.

MEKALA P, PUNNIAMURTHY N, HARIHARAN P 2006: Protective effect of curcumin and silymarin against aflatoxicosis in broiler chicken Indian Vet J 83: 501-503

RASTOGI R, SRIVASTAVA AK, SRIVASTAVA M, RASTOGI AK 2000: Hepatocurative effect of picroliv and silymarin against aflatoxin B-1 induced hepatotoxicity in rats. Planta Med 66: 709-713

SALLER R, MEIER R, BRIGNOLI R 2001: The use of silymarin in the treatment of liver diseases. Drugs 61: 2035-2063

SALMI HA, SARNA S 1982: Effect of silymarin on chemical, functional, and morphological alterations of the liver - a double-blind controlled-study. Scand J Gastroenterol 17: 517-521

SINGH RP, AGARWAL R 2004: Prostate cancer prevention by silibinin. Cur Cancer Drug Targets 4: 1-11

SOTO C, MENA R, LUNA J, CERBON M, LARRIETA E, VITAL P, URIA E, SANCHEZ M, RECOBA R, BARRON H, FAVARI L, LARA A 2004: Silymarin induces recovery of pancreatic function after alloxan damage in rats. Life Sci 75: 2167-2180

SOTO C, RECOBA R, BARRON H, ALVAREZ C, FAVARI L 2003: Silymarin increases antioxidant enzymes in alloxan-induced diabetes in rat pancreas. Comp Biochem Physiol C-Toxicol Pharmacol 136: 205-212 
SUJATHA K, MATHURAM LN, SRIRAM P 2003: Hepatoprotective effect of silymarin in experimentally induced aflatoxicosis in broilers. Toxicol Int 10: 55-59

ŠKOTTOVÁ N, KREČMAN V 1998: Silymarin as a potential hypocholesterolaemic drug. Physiol Res 47: 1-7

TEDESCO D, STEIDLER S, GALLETTI S, TAMENI M, SONZOGNI O, RAVAROTTO L 2004: Efficacy of silymarin-phospholipid complex in reducing the toxicity of aflatoxin B1 in broiler chicks. Poult Sci 83: 1839 1843

VACEK Z 1990: Histológia a histologická technika. (Histology and histology techniques), (in Slovak). Osveta Press, Martin, 504 p.

VIJAYAKUMAR G, SUBRAMANIAN M, SRINIVASAN SR 2004: Efficacy of silymarin as hepatoprotectant in oxytetracycline induced hepatic disorder in dogs. IndianVet J 81: 37-39

WELLINGTON K, JARVIS B 2001: Silymarin: A review of its clinical properties in the management of hepatic disorders. Drug evaluation. Biodrugs 15: 465-489

WOJCIK S, NIEDZWIADEK T, ADAMCZYK M 2002: The effectiveness of silymarin in finishing broilers. Biuletyn Naukowy Przemyslu Paszowego 41: 5-14 
Plate I

Suchý P. Jr. et al.: Hepatoprotective ... pp. 31-38

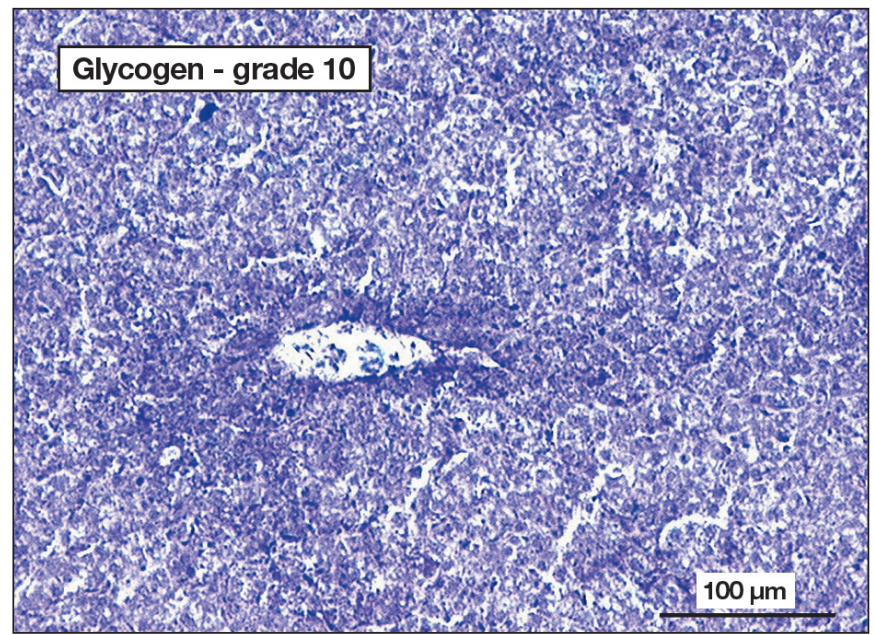

Fig. 1. Low content (grade 10) of glycogen in the liver of both control groups of chickens K(-) and $\mathrm{K}(+)$, and in the experimental group with lower supplement of silymarin and chlortetracycline medication $\mathrm{P} 1(+)$

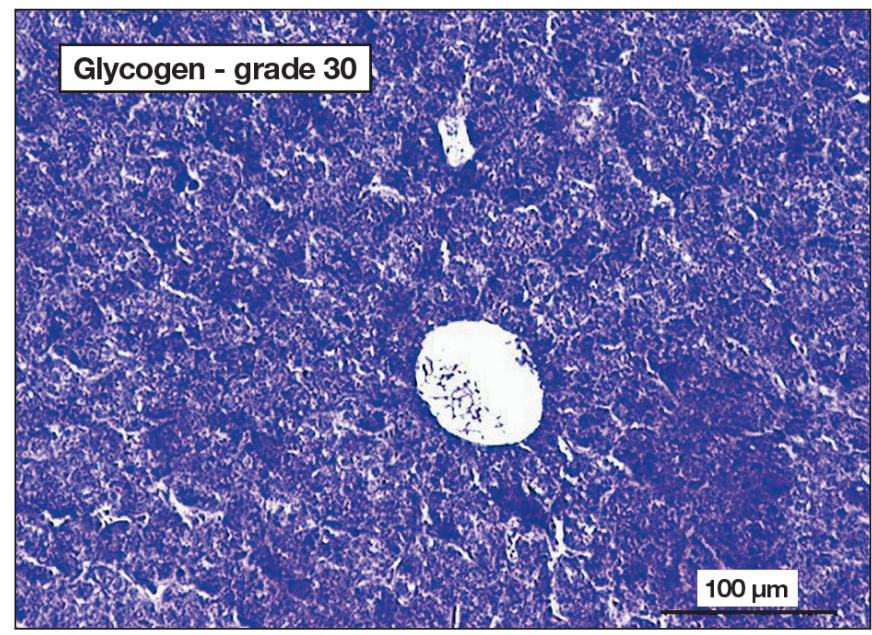

Fig. 2. High content (grade 30) of glycogen in the liver was present in the experimental groups of chickens in the case of lower silymarin doses only in the group without the application CTC P1(-), and in case the of higher silymarin doses also when administered CTC - P2(-) and P2(+) 


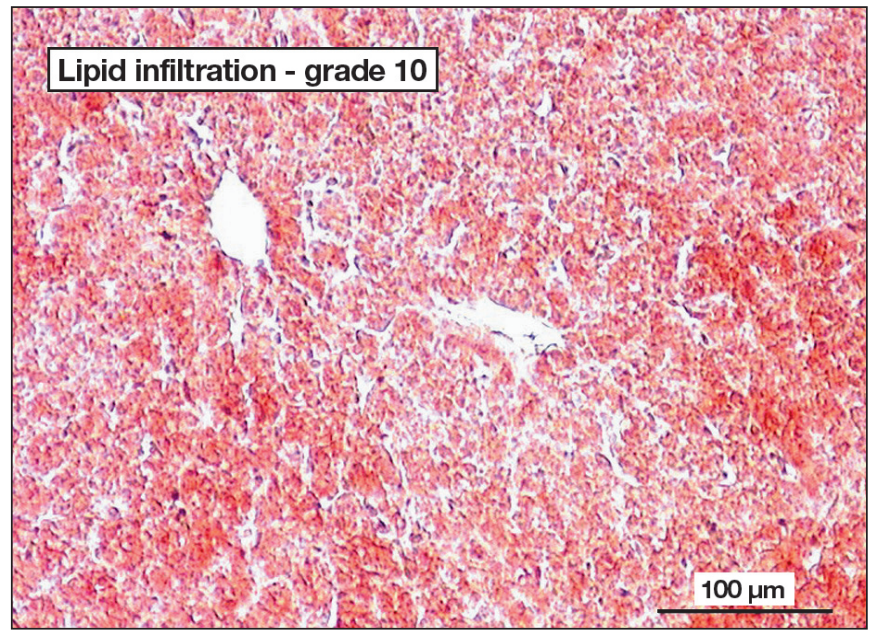

Fig. 3. Low content (grade 10) of lipids in the liver was found in both experimental groups of chickens without medication CTC - P1(-) and P2(-)

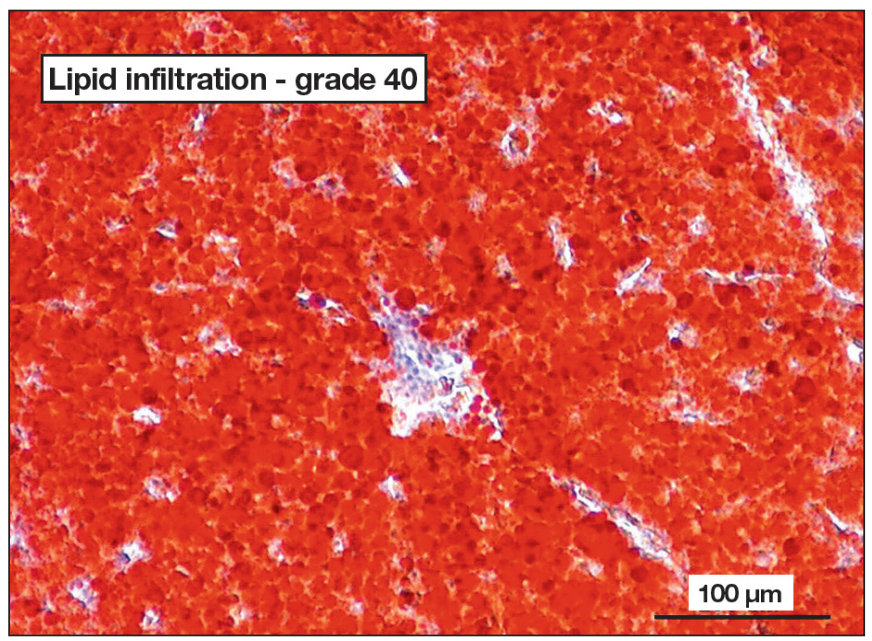

Fig. 4. A characteristic picture of the control group of chickens exposed to CTC $\mathrm{K}(+)$ and of the experimental group of chickens exposed to CTC with lower silymarin doses P1(+) was a high degree of liver steatosis showing signs of hepatocyte dystrophy (grade 40 - large fat drops form) 